\title{
Technical and Operating Support for Pilot Demonstration of Morphysorb Acid Gas Removal Process
}

\author{
Quarterly Report No. 3 \\ Reporting Period Start Date: July1, 2003 \\ Reporting Period End Date: September 30, 2003 \\ Principal Authors \\ Nagaraju (Raj) Palla \\ Dennis Leppin \\ GTI Project 61166
}

Contract Number: DE-FC26-01NT41028

To

Anthony M. Zammerilli

Project Manager

National Energy Technology Laboratory

P.O. Box 880

3610 Collins Ferry Road

Morgantown, WV 26507

By

\author{
GAS TECHNOLOGY INSTITUTE \\ 1700 South Mount Prospect \\ Des Plaines, IL 60018-1804
}


Technical and Operating Support for a Morphysorb Process Demonstration

GTI Project 61166 Contract Number: DE-FC26-01NT41028

\section{DISCLAIMER}

This report was prepared as an account of work sponsored by an agency of the United States Government. Neither the United States Government nor any agency thereof, nor any of their employees, makes any warranty, express or implied, or assumes any legal liability or responsibility for the accuracy, completeness, or usefulness of any information, apparatus, product, or process disclosed, or represents that its use would not infringe privately owned rights. Reference herein to any specific commercial product, process, or service by trade name, trademark, manufacturer, or otherwise does not necessarily constitute or imply its endorsement, recommendation, or favoring by the United States Government or any agency thereof. The views and opinions of authors expressed herein do not necessarily state or reflect those of the United States Government or any agency thereof. 


\title{
Technical and Operating Support for a Morphysorb Process Demonstration
}

\author{
GTI Project 61166 Contract Number: DE-FC26-01NT41028
}

\begin{abstract}
GTI and Krupp Uhde have been jointly developing advanced technology for removing high concentrations of acid gas from high-pressure natural gas for over a decade. This technology, the Morphysorb ${ }^{\circledR}$ process, based on $\mathrm{N}$-formyl and $\mathrm{N}$-acetyl morpholine mixtures, has now been tested in a large-scale facility and this paper presents preliminary results from acceptance testing at that facility. Earlier publications have discussed the bench-scale and pilot plant work that led up to this important milestone.
\end{abstract}

The site was Duke Energy's new Kwoen sour gas upgrader near Chetwynd B.C., Canada. This facility has a nameplate capacity of $300 \mathrm{MMscfd}$ of sour natural gas. The objective of the Morphysorb process at this site was to remove $33 \mathrm{MMscfd}$ of acid gas $\left(\mathrm{H}_{2} \mathrm{~S}\right.$ and $\mathrm{CO}_{2}$ ) for reinjection downhole. This represents about half the acid gas present in the feed to the plant. In so doing, proportionately more of the plant "sales" gas, which is sent for final processing at the nearby Pine River plant, can be sent down the line without coming up against the sulfur removal capacity limits of Pine River plant, than could with other solvents that were evaluated. Other benefits include less loss of methane downhole with the rejected acid gas and lower circulation and recycle compression horsepower than with competitive solvents. On the downside, the process is expected to have higher solvent vaporization losses than competitive solvents, but this is a comparatively minor drawback when weighed against the value of the benefits. These benefits (and drawbacks) were developed into quantitative "acceptance" criteria, which will determine if the solvent will continue to be used at the site and for award of monetary bonuses to the process developer (GTI). 
Technical and Operating Support for a Morphysorb Process Demonstration GTI Project 61166 Contract Number: DE-FC26-01NT41028

$\underline{\text { TABLE OF CONTENTS }}$

EXECUTIVE SUMMARY 6

$\begin{array}{ll}\text { EXPERIMENTAL } & 7\end{array}$

RESULTS AND DISCUSSION 8

$\begin{array}{ll}\text { CONCLUSION } & 9\end{array}$

$\begin{array}{ll}\text { REFERENCES } & 9\end{array}$

LIST OF ACRONYMS AND ABBREVATIONS 10

APPENDIX A 11 


\title{
Technical and Operating Support for a Morphysorb Process Demonstration
}

\author{
GTI Project 61166 Contract Number: DE-FC26-01NT41028
}

\section{INTRODUCTION}

GTI and Uhde have been jointly developing advanced technology for removing high concentrations of acid gas from high-pressure natural gas for over a decade. This technology, the Morphysorb ${ }^{\circledR}$ process, based on $\mathrm{N}$-formyl morpholine and $\mathrm{N}$-acetyl morpholine mixtures, has now been tested in a large-scale facility at Duke Energy plant in Canada. Earlier publications have discussed the bench-scale and pilot plant work that led up to this important milestone.

Morphysorb ${ }^{\circledR}$ is a physical solvent-based process used for the bulk removal of $\mathrm{CO}_{2}$ and/or $\mathrm{H}_{2} \mathrm{~S}$ from natural gas and other gaseous streams. The solvent consists of N-Formyl morpholine and other morpholine derivatives. This process is particularly effective for high-pressure and high acid-gas applications and offers substantial savings in investment and operating cost compared to competitive physical solvent-based processes.

Over the past 6 years, GTI in coordination with Uhde GmbH (GTI's commercialization partner) has conducted over $100+$ field experiments processing more than $50 \mathrm{MMscf}$ at the Shell-owned (now Kinder Morgan-owned) Fandango plant site in south Texas using the GTI (IGT) pilot plant unit.

GTI has negotiated an agreement Duke Energy Gas Transmission, Canada (DEGTC is a wholly owned subsidiary of Duke Energy) to test the Morphysorb process in a field experiment in their Kwoen plant, near Chetwynd BC, Canada which, if successful, can be the first commercial application of Morphysorb This plant processes $300 \mathrm{MMscfd}$ of sour gas (over 23\% acid gas concentration). In that plant the target is to remove $30 \mathrm{MMscfd}$ of sour gas for reinjection. The balance of the sweetened gas, which is still quite sour, is sent to another plant for final acid gas removal and sulfur recovery using conventional technology.

This field experimental test of Morphysorb was carried out at Duke Energy's Kwoen Plant in November 2002. The test objectives were to demonstrate Morphysorb operability in a commercial unit and to confirm that the advantages observed in the pilot plant could be achieved on a commercial scale and could meet the specific performance targets as agreed in GTI's demonstration agreement with Duke Energy. The process is commercially licensed to DEGTC under a separate agreement with Uhde.

GTI's role was to develop test criteria for validation test (such as length of the test, criteria for steady state), parameters measured, determine the sampling location and sampling frequency analysis of data, set up a lab trailer, design sampling loops, observe and conduct performance test and sample collection, analysis of test data and report preparation. 


\title{
Technical and Operating Support for a Morphysorb Process Demonstration
}

\author{
GTI Project 61166 Contract Number: DE-FC26-01NT41028
}

\section{EXECUTIVE SUMMARY}

GTI and Duke Energy Gas Transmission Company, Inc. Canada (DEGTC) have entered into an agreement to test the performance of the Morphysorb ${ }^{\circledR}$ solvent (jointly owned by Uhde and GTI) in DEGTC's Kwoen Sour Gas Upgrader plant near Chetwynd, B.C., Canada. As part of that agreement, GTI is required to conduct a performance test at the Kwoen plant of 72 hours duration. Gas sampling and analytical equipment in a laboratory trailer was set up in anticipation of this requirement.

The test was conducted over the period November 12 - November 15, 2002. The testing resulted in two useful "steady-state" periods (which differ in conditions significantly from each other) for the purpose of computation of the adjusted performance specification metric values and analysis of resultsIn all cases the performance metrics satisfied the established criteria by being either less than adjusted maximum values or greater than minimum adjusted values.

The Morphysorb performance is assessed by Duke Energy according to five metrics: acid gas pickup, recycle gas flow, total hydrocarbon loss in acid gas stream, Morphysorb solvent losses and foaming related problems. Plant data over a period of one year show that the Morphysorb solvent has performed extremely well in four out of five of these categories. The fifth metric, Morphysorb solvent loss, is being evaluated over a longerterm period in order to accurately assess it. However, the preliminary indications based on makeup solvent used to date are that solvent losses will also be within expectations. The analysis of the solvent samples indicates that the solvent is very stable and did not show any sign of degradation. The operability of the solvent is good and no foaming related problems have been encountered. According to plant operators the Morphysorb unit runs smoothly and requires no special attention.

GTI has continued monitoring the Kwoen plant performance and collect crucial design data for future commercial applications of the Morphysorb process during this reporting period. These data was quite helpful in ensuring the smooth running of the plant and in avoiding potential operational problems associated with corrosion, foaming, off spec gas and reduced performance. This report is an evaluation of such analytical efforts from samples received through mid-September of 2003.

Morphysorb Process at Duke Energy's Kwoen plant is operating successfully without any solvent related problems. As of end of September, approximately $72 \mathrm{Bcf}$ of gas processed since plant startup in August' 02 and injected 6.2 BCF to the injection well. 


\title{
Technical and Operating Support for a Morphysorb Process Demonstration
}

\author{
GTI Project 61166 Contract Number: DE-FC26-01NT41028
}

\section{EXPERIMENTAL}

\section{Task 1: $\quad$ Morphysorb Demonstration Plant}

The overall objective Morphysorb demonstration project to prove earlier laboratory and simulation predictions for overall cost savings at Duke facility by removing acid gas from subquality natural gas by utilizing a new physical solvent system.

The role of GTI is limited to assist in basic design engineering services based on the GTI's knowledge acquired through lab, bench-scale and pilot plant experiments, in procuring plant facilities, plant start-up, establishing analytical set up for evaluating plant/technology performance, data collection, analysis and report preparation.

Morphysorb Process at Duke Energy's Kwoen plant is operating successfully without any solvent related problems. As of end of September, approximately 72 Bcf of gas processed since plant startup in August' 02 and injected $~ 6.2$ BCF to the injection well.

As part of agreement with Duke Energy, GTI is obligated to analyze the solvent samples once a month until February'04 and keep track of solvent stability and performance. To date, a total of seven sample sets analyzed as per details provided in the following Table 1.

Table 1. Morphysorb Solvent Samples

\begin{tabular}{|l|l|l|}
\hline Sample & $\begin{array}{l}\text { Date } \\
\text { Collected }\end{array}$ & Remarks \\
\hline Virgin & July 2002 & $\begin{array}{l}\text { This sample was collected soon after the solvent } \\
\text { was loaded into the plant and recirculated 48 hours } \\
\text { for proper mixing. }\end{array}$ \\
\hline 1 & $\begin{array}{l}\text { November } \\
15,2002\end{array}$ & $\begin{array}{l}\text { This sample was collected on November 15, 2002 } \\
\text { during plant performance testing. }\end{array}$ \\
\hline 2 & $\begin{array}{l}\text { November } \\
28,2002\end{array}$ & $\begin{array}{l}\text { This sample was collected on November 28, 2002 } \\
\text { during GTI staff visit to the plant. }\end{array}$ \\
\hline 3 & $\begin{array}{l}\text { March 14, } \\
2003\end{array}$ & $\begin{array}{l}\text { This sample was collected by Duke Energy and } \\
\text { shipped to GTI in April 2003. }\end{array}$ \\
\hline 4 & $\begin{array}{l}\text { April 20, } \\
2003\end{array}$ & $\begin{array}{l}\text { This sample was collected by Duke Energy and } \\
\text { shipped to GTI in May 2003. }\end{array}$ \\
\hline 5 & $\begin{array}{l}\text { June 6, } \\
2003\end{array}$ & $\begin{array}{l}\text { This sample was collected by Duke Energy and } \\
\text { shipped to GTI in June 2003. }\end{array}$ \\
\hline 6 & $\begin{array}{l}\text { July 25, } \\
2003\end{array}$ & $\begin{array}{l}\text { This sample was collected by Duke Energy and } \\
\text { shipped to GTI in August 2003. }\end{array}$ \\
\hline
\end{tabular}




\title{
Technical and Operating Support for a Morphysorb Process Demonstration
}

\author{
GTI Project 61166 Contract Number: DE-FC26-01NT41028
}

To assess the solvent stability, GTI has conducted the following analysis on all the above samples.

- N-Formyl morpholine, N- Acetyl morpholine, Morpholine and Water

- Hydrocarbons

- Traces of organic N-compounds

- Formate, Acetate, Oxalate, Chloride and Sulfate

- Silica

- ICP/OES Analysis for metals (Na, K, Mg, Ca, Sr, Ba, Ti, V, Cr, Mo, Mn, Fe, Co, $\mathrm{Ni}, \mathrm{Cu}, \mathrm{Zn}, \mathrm{Cd}, \mathrm{Al}, \mathrm{Sn}, \mathrm{Pb}, \mathrm{As}, \mathrm{Sb}, \mathrm{Se})$

- Sulfur and Phosphorous

- Measuring of the content and analysis of solids filtering with 0.2 micron PTFE membrane filter. Analysis of solids: TOC, total sulfur, total nitrogen by combustion method.

\section{RESULTS AND DISCUSSION}

GTI is interested in obtaining continuing data on the plant to support future plants and DEGTC is interested in reviewing data that may help in operating the plant and in avoiding various difficulties including corrosion, foaming, off spec gas and reduced performance. GTI will continue to receive samples and analyze. GTI has made a PowerPoint presentation to Duke Energy's Kwoen plant management and its staff with detailed information on plant samples collected to date. The details are as follows:

1. Provided a detailed account of actual solvent additions to date and projected solvent losses. With a detailed information at hand, DEGTC agreed that the solvent losses are either the same or less than earlier projections.

2. Provided detailed information on iron content in the solution. Duke Energy is very satisfied with solvent corrosion performance and in fact claimed that, once the plant went into operational, actual corrosion rates have come down.

3. The analysis of solvent samples indicates that solvent is very stable after one year of continuous operation and did not undergo any appreciable formation of solvent degradation products that would affect the solvent performance. 


\title{
Technical and Operating Support for a Morphysorb Process Demonstration
}

\author{
GTI Project 61166 Contract Number: DE-FC26-01NT41028
}

4. Overall, Duke Energy is pleased with Morphysorb solvent performance and requested GTI to review one of their nearby gas processing plants for possible Morphysorb application.

\section{Work for Next Quarter:}

GTI will continue to monitor plant performance and provide any technical assistance as required by Duke Energy from time to time. GTI will also receive and analyze the solvent samples collected during next quarter.

\section{CONCLUSION}

Morphysorb Process at Duke Energy's Kwoen plant is operating successfully without any solvent related problems. As of end of September, approximately $72 \mathrm{Bcf}$ of gas processed since plant startup in August' 02 and injected $\sim 6.2$ BCF to the injection well.

\section{REFERENCES}

1. Hugman, V. and Springer, "Chemical Composition of Discovered and Undiscovered Natural Gas in the U.S. Lower-48, March 1993, Energy and Environmental Analysis, Inc.

2. Tannehill, C. C. and Gibbs, J. E., "Gas Processing Industry Lower 48 States," July 1991, Purvin \& Gertz, Inc., GRI-911/0232.

3. Macriss, R. A., and Duncan, D., "Acid-Gas and Trace Impurity Removal," Annual Report for 1975, A.G.A Project No. IU-4-10, 1976.

4. N. Palla, A. L. Lee, Dr. M. Gross, H. M. Hooper, J. Menzel and D. Leppin "Advancements in Treating Subquality Natural Gas Using N-Formyl Morpholine", Proceedings of the 77th GPA Annual Convention, 1998

1. M. Gross et al., "A New Solvent Process for Acid Gas Removal and its Impact on BTEX Emissions", Proceedings of the $49^{\text {th }}$ Laurance Reid Gas Conditioning Conference, February 1999

2. M.Gross, J. Menzel," Acid Gas Removal for Upgrading natural and Synthesis Gas-Part I", paper published in Hydrocarbon Engineering, November 1997.

3. M.Gross, J.Menzel," Acid Gas Removal for Upgrading natural and Synthesis Gas-Part II", paper published in Hydrocarbon Engineering, June 1998. 
Technical and Operating Support for a Morphysorb Process Demonstration GTI Project 61166 Contract Number: DE-FC26-01NT41028

\section{LIST OF ACRONYMS AND ABBREVIATIONS}

NFM-N-Formyl Morpholine

NAM-N-Acetyl Morpholine

Scf-Standard Cubic Feet

Gal-Gallons

MM-Million

DEGTC_-Duke Energy Gas Transmission Company

GTI-Gas Technology Institute

KU-Krupp Uhde 
Technical and Operating Support for a Morphysorb Process Demonstration GTI Project 61166 Contract Number: DE-FC26-01NT41028

\section{Appendix A Article Published in GTI/DOE GasTIPS Publication}




\section{Status Report: Operation of the Morphysorb ${ }^{\circledR}$ Process at a Canadian Gas Treating Plant}

\section{Authors: Raj Palla, Dennis Leppin and Aqil Jamal, GTI}

Morphysorb ${ }^{\circledR}$ is a physical solvent-based process used for the bulk removal of $\mathrm{CO}_{2}$ and/or $\mathrm{H}_{2} \mathrm{~S}$ from natural gas and other gaseous streams. The solvent consists of N-Formyl morpholine and other morpholine derivatives. This process is particularly effective for high-pressure and high acid-gas applications and offers substantial savings in investment and operating cost compared to competitive physical solvent-based processes.

GTI and Duke Energy Gas Transmission Company (DEGTC) first entered into an agreement in 2002 to test the Morphysorb process at their Kwoen Gas Treating Plant in northern BC. Details on the Morphysorb technology and the project background were published earlier in the Winter 2003 issue of GasTips (p. 28-32). The purpose of this article is to update the reader on the process performance after 300 days of continuous operation.

The process is operating successfully without any solvent related problems and has between DEGTC and GTI. As of June 2003, about 49 Bcf of sour gas was processed. Of this about 4 Bcf of acid gas containing mainly $\mathrm{H}_{2} \mathrm{~S}$ and $\mathrm{CO}_{2}$ was injected back into the depleted reservoir and 45 Bcf sent for further processing at DEGTC's Pine River Plant. The weekly averages of the feed, product, recycle and acid gas flows are shown in Figure 1. As can be seen from this figure, the plant has been operating close to its full capacity (300 MMscfd) for the last four months.

GTI continues to monitor the Kwoen plant performance and collect crucial design data for future commercial applications of the Morphysorb process. These data will be quite helpful in ensuring the smooth running of the plant and in avoiding potential operational problems associated with corrosion, foaming, off spec gas and reduced performance. GTI collects Morphysorb solvent samples from this plant once a month and analyzes to monitor solvent composition, water content and degradation products. Thus far GTI has collected and analyzed six solvent samples from the Kwoen plant since its startup in August 2002. GTI will continue to collect these samples until the end of 2003.

\section{Solvent Thermal and Chemical Stability:}

The solvent analysis at GTI indicates that the Morphysorb solvent is very stable after ten months of operation. No solvent degradation has been observed and the solvent composition is similar to the initial startup value. Total makeup solvent added to date is less than predicted initially. The total solvent loss will be further verified by analyzing product gas and acid gas samples after the plant has operated at its full capacity for some time.

NFM and NAM are the products of reaction of morpholine with formic and acetic acid respectively. The solvent samples were analyzed for thermal and chemical degradation 


\section{Technical and Operating Support for a Morphysorb Process Demonstration}

\section{GTI Project 61166 Contract Number: DE-FC26-01NT41028}

products such as formate, acetate, sulfate, oxalate and chloride. The concentrations of anions are quite constant over the period of the last several months and there has not been a significant change since plant start-up.

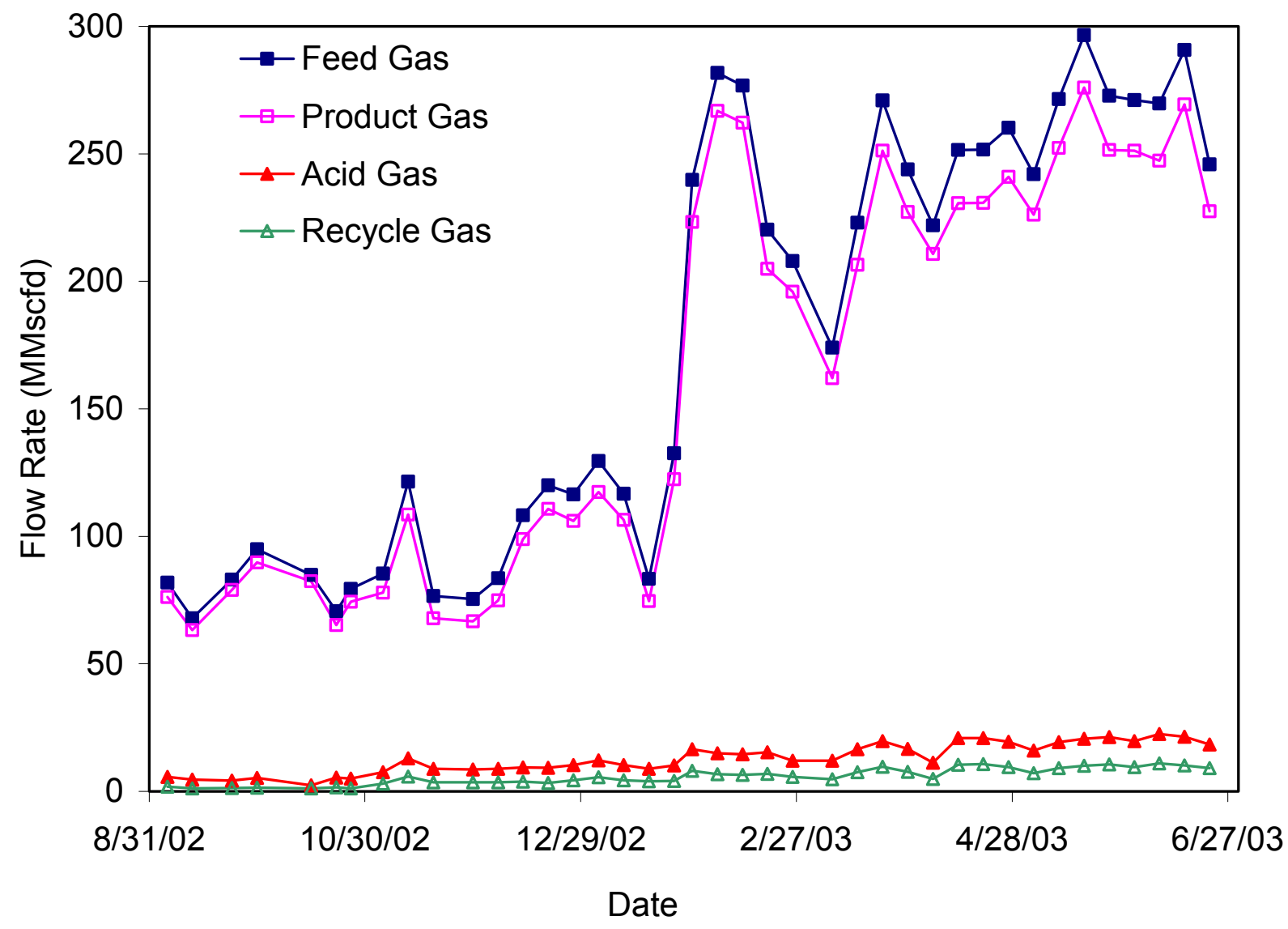

Figure 1: Weekly Averages of Feed, Product, Recycle and Acid Gas Flows Since Kwoen Plant Commissioning

\section{Accumulation of Higher Hydrocarbons:}

Our analysis shows that the concentration of higher hydrocarbons in the solvent has increased over time. This phenomenon is quite common in any gas treating plant using physical solvents. The accumulation of heavies in the solvent and their effect on solvent performance should continue to be monitored closely. GTI plans to track the accumulation of heavies in the solvent samples collected monthly and see if a steady concentration is reached. There are various procedures, which can be implemented if the concentration of heavies increases beyond an acceptable limit. 


\title{
Technical and Operating Support for a Morphysorb Process Demonstration
}

\author{
GTI Project 61166 Contract Number: DE-FC26-01NT41028
}

\section{Accumulation of Iron in Solvent:}

We also observed that the iron $(\mathrm{Fe})$ content in the solvent is increasing over time. We expect this to level off in the near future. A slow increase in iron concentration in the solvent from start-up to the present is likely the result of a typical passivation process at the carbon steel surface.

\section{Solvent Foaming:}

So far no foaming incidents or process related upsets have occurred. As indicated earlier about $50 \mathrm{Bcf}$ gas has been processed so far and no antifoam agent has been used.

\section{Total Hydrocarbon Losses in Acid Gas Stream:}

The methane content in the acid gas is continuously monitored using an online analyzer. The total methane losses are in the range of 0.95 to $1.2 \mathrm{~mole} \%$. This is one of the strongest advantages of this process. By our calculations methane losses are 3 to 4 times lower than competing physical solvent process.

\section{Overall Solvent Performance:}

The Morphysorb performance is assessed by Duke Energy according to five metrics: acid gas pickup, recycle gas flow, total hydrocarbon loss in acid gas stream, Morphysorb solvent losses and foaming related problems. Plant data over a period of ten months show that the Morphysorb solvent has performed extremely well in four out of five of these categories. The fifth metric, Morphysorb solvent loss, is being evaluated over a longerterm period in order to accurately assess it. However, the preliminary indications based on makeup solvent used to date are that solvent losses will also be within expectations. The analysis of the solvent samples indicates that the solvent is very stable and did not show any sign of degradation. The operability of the solvent is good and no foaming related problems have been encountered. According to plant operators the Morphysorb unit runs smoothly and requires no special attention. 